\title{
George Papanicolaou (1883-1962): Discoverer of the Pap Smear
}

\author{
Vijayalakshmi Chandrasekhar ${ }^{1} \cdot$ Chandrasekhar Krishnamurti $^{2}$
}

Received: 5 February 2018/Accepted: 23 February 2018/Published online: 26 March 2018

(C) Federation of Obstetric \& Gynecological Societies of India 2018

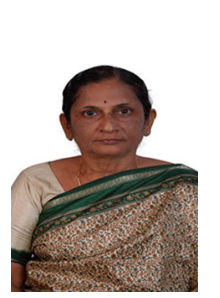

\begin{abstract}
About the Author
Dr. Vijayalakshmi Chandrasekhar, M.D., D.G.O., M.B.A. (HA) Dr. Vijayalakshmi Chandrasekhar is presently an Assistant Professor in Obstetrics and Gynecology at the GITAM Institute of Medical Sciences and Research at Visakhapatnam, Andhra Pradesh. She graduated with M.B.B.S. degree from the Andhra Medical College at the top of her class, secured medals in physiology, pathology, medicine, midwifery and also adjudged the best outgoing student by the Ministry of Health and Family Welfare, New Delhi, in 1979 with President's Silver Medal for scoring the highest marks in M.B.B.S. at the National level. She obtained her D.G.O. in 1983 and M.D. in 1984 and is registered with the AP medical council. Married to a Naval officer and anesthesiologist, she worked at family clinics at various Naval stations and was a co-worker on an ICMR research project at the Nowrosjee Wadia Maternity Hospital at Mumbai on computerization of obstetric records in 1991. Her main interests are social obstetrics, perinatal medicine and cardiotocography. She is a life member of the Mumbai Obstetric and
\end{abstract} Gynecological Society and has an MBA in Hospital Administration from Andhra University.

Dr. Vijayalakshmi Chandrasekhar, M.D., D.G.O. is an Assistant Professor, Department of Obstetrics and Gynecology, GITAM Institute of Medical Sciences and Research; Dr. Chandrasekhar Krishnamurti, M.D., is an Associate Professor, Department of Anesthesiology, NRI Institute of Medical Sciences.

Vijayalakshmi Chandrasekhar

Svijaya2003@yahoo.com

1 Department of Obstetrics and Gynecology, GITAM Institute of Medical Sciences and Research, Rushikonda, Visakhapatnam 530045, India

2 Department of Anesthesiology, NRI Institute of Medical Sciences, Sangivalasa, Bheemlipatnam, Visakhapatnam 530003, India
Abstract Born in 1883 in Kyme, Greece, George Papan-
icolaou obtained his medical degree in 1904 from the
University of Athens and doctorate in Zoology in 1910
from the University of Munich. He migrated to the USA in
1913 and worked as an assistant at the Department of
Anatomy in the Cornell Medical College. There, Papani-
colaou examined vaginal smears under his microscope,
charted the cyclic ovarian and uterine changes every day
and harvested the oocytes at the appropriate time. He
published his research on the cytologic patterns in guinea
pigs in the American Journal of Anatomy in 1917. Even-
tually, he began taking similar scrapings from women and
noticing malignant cells in smears taken from women with
cancer. In 1928, his presentation on the topic at the Race
Betterment Conference in Battle Creek, Michigan, was 
greeted with skepticism as researchers felt that a biopsy and tissue examination was the only way to detect the disease. In 1939, he collaborated on a clinical study with Herbert F. Traut, MD, a gynecologic pathologist at Cornell, to validate the diagnostic potential of the vaginal smear and published their landmark paper in 1943 titled "Diagnosis of uterine cancer by the vaginal smear." In 1954, Papanicolaou published the "Atlas of Exfoliative Cytology."

George Nicholas Papanicolaou was a pioneer in cytopathology and creator of the Papanicolaou test or Pap smear. This revolutionized the early detection of cervical cancer and led to a $70 \%$ reduction in cervical cancer deaths.

Keywords Cervical cancer · Screening · Pap smear

\section{Introduction}

George Papanicolaou (Dr. Pap) was a pioneer in cytopathology and inventor of the "Pap smear" for early detection of uterine cancer. He was a dedicated, modest and hardworking scientist, who immersed himself in the wonders of cytopathology. His 1954 publication Atlas of Exfoliative Cytology created the foundation of the modern cytopathology. In 1961, he established the Cancer Institute of Miami.

\section{Biography of a Biologist}

\section{His Early Years}

Born on May 13, 1883, in the town of Kimi on the island of Euboea, Greece, Papanicolaou was one of four children. He attended the University of Athens, majoring in music and the humanities. Under the influence of his physician father, Papanicolaou decided to pursue a career in medicine and graduated from the University of Athens in 1904 with top honors. He then did military service as an assistant surgeon and then returned to his hometown to care for leprosy patients for 2 years.

In 1910, Papanicolaou was awarded a Ph.D. in Zoology for his thesis, "Sex differentiation of the daphnia" from the University of Munich, Germany. He returned to Athens in 1910 and relocated to Monaco after his marriage at the Oceanographic Institute. In July 1911, he joined a marine research expedition in the Mediterranean Sea and Atlantic Ocean led by the Prince Albert of Monaco. During the First Balkan War in 1912, Papanicolaou returned to military service as a lieutenant in Greece's medical corps, while in the army, he met several American volunteers who told him about the many career opportunities in the USA.

\section{His Life's Turning Point}

In 1913, Papanicolaou emigrated to the USA and, after a year's work as a rug salesman, violin player in a restaurant and a clerk in a Greek newspaper, he obtained entry into the New York University's Pathology department and Cornell University medical college's anatomy department [1-3].

In 1916, while studying sex chromosomes in guinea pigs, he observed that their reproductive cycles could be timed by examining smears of their vaginal secretions. In 1920 , he ventured to study the cytology of the human reproductive system and in 1928, Papanicolaou reported that uterine cancer could be diagnosed by means of a vaginal smear [4]. The importance of his work was not recognized. In 1941, he published a paper on the diagnostic value of vaginal smears in carcinomas of the uterus and followed it up by publishing a book, 2 years later, in collaboration with a gynecological pathologist Dr. Herbert Traut (1894-1963), titled "Diagnosis of Uterine Cancer by the Vaginal Smear" [5, 6]. This landmark publication had a global impact and the Pap smear, or Pap test, became the gold standard in screening for cervical cancers. Widespread use of the test resulted in a significant $70 \%$ decline in the incidence of deaths due to cervical cancer (Fig. 1).

\section{His Pioneering Efforts}

In 1951, Papanicolaou became an Emeritus Professor at the Cornell University Medical College. In 1954, he published another memorable work, the Atlas of Exfoliative Cytology. This laid the foundation of the modern medical specialty of cytopathology. In 1961, he relocated to develop and head the Cancer Institute of Miami (Fig. 2).

He died within three months of his arrival in Miami, suffering a fatal myocardial infarction on February 19, 1962. He was 78 years old.

\section{His Good Work Recognized}

Papanicolaou wrote more than 150 scientific articles and was the recipient of the Borden Award of the Association of American Medical Colleges (1940), the Amory Prize from the American Academy of Arts and Sciences (1947), the Albert Lasker Award for Clinical Medical Research from the American Public Health Association (1950) and the Medal of Honor from the American Cancer Society (1952). He was elected as an honorary Fellow of the Academy of Athens. In 1960, he was nominated for the Nobel Prize in Physiology and Medicine, and he was 
Fig. 1 A 1972 first day cover issued by Greece honoring Dr. Papanicolaou the legendary cytopathologist

Fig. 2 The Miami Institute of Cancer also known as the Papanicolaou Cancer Research Institute

Fig. 3 Greek 10,000 drachma currency note issued in honor of Dr. Papanicolaou
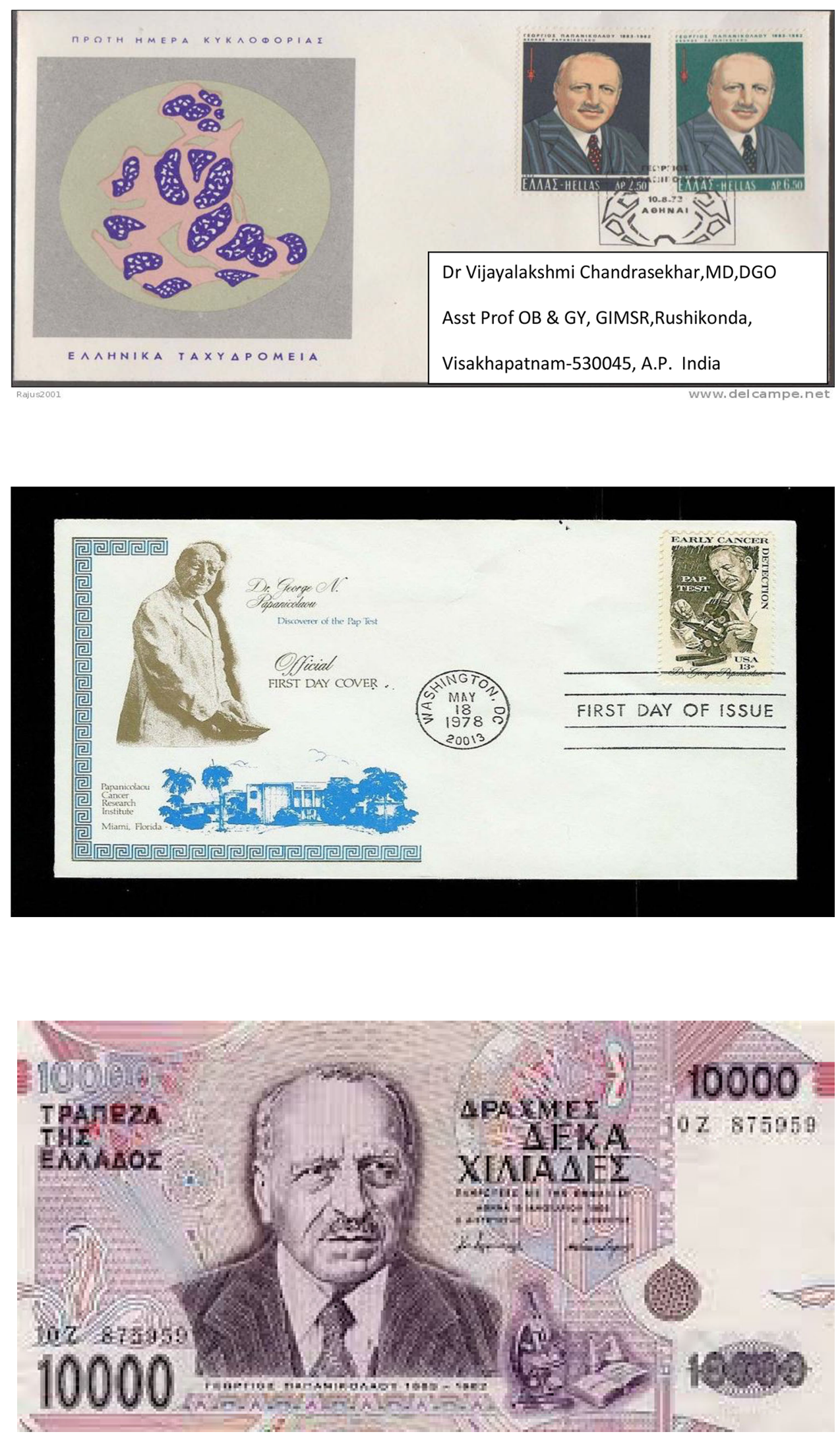
Fig. 4 US Postal department first day cover on early cancer detection and the "Pap test"

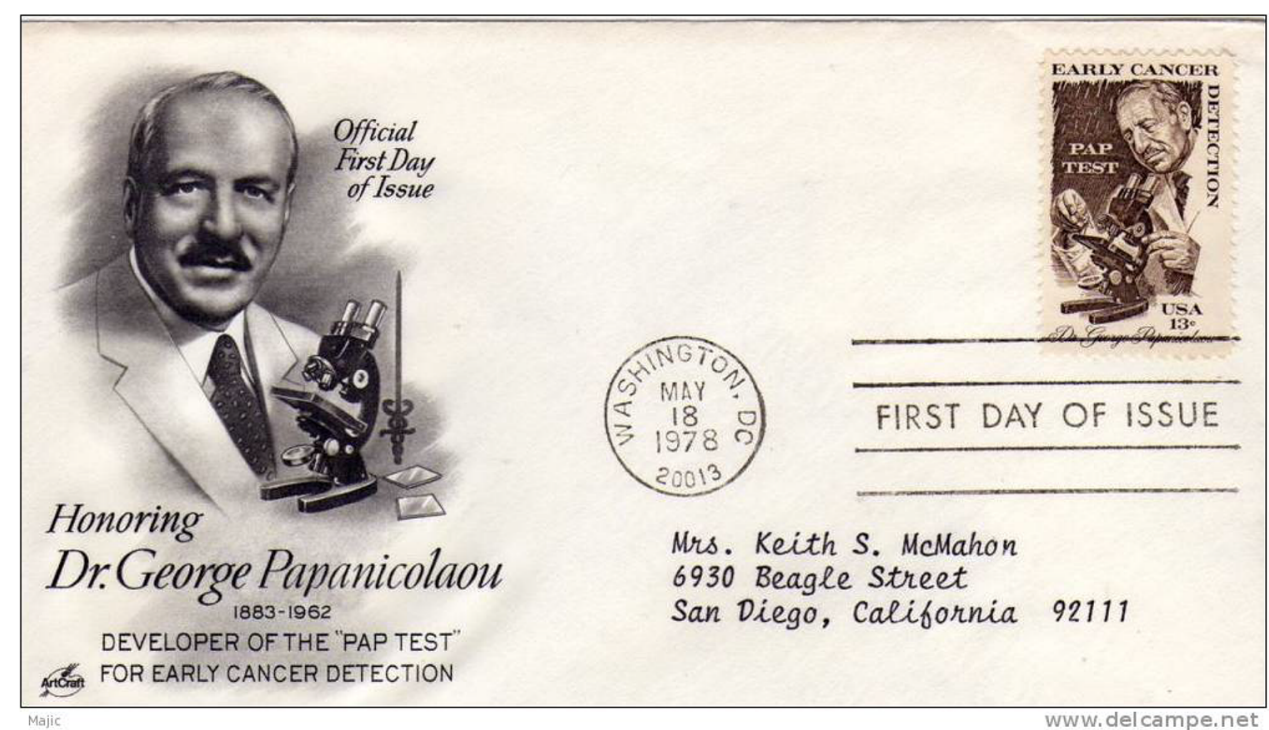

awarded the United Nations Prize in 1962. His image was featured on the Greek 10,000 drachma currency note prior to its replacement by the euro and on various Greek stamps (Fig. 3). In 1978, the US Postal Service honored him with a commemorative 13-cent postage stamp (Fig. 4).

\section{Compliance with Ethical Standards}

Conflict of interest The authors Dr. Vijayalakshmi Chandrasekhar and Dr. Chandrasekhar Krishnamurti declare that they have no conflict of interest and have not received any research grants or honorarium, and no ethical issues are involved in preparation of the paper submitted.

Ethical Standards Permission has been obtained for copyrighted images in our historical article titled "George Papanicolaou (1883-1962): Discoverer of the Pap smear”.

\section{References}

1. Carmichael DE. The Pap smear: life of George N. Papanicolaou. Springfield: Charles C Thomas Pub Ltd; 1973.

2. Papanikolaou MSG. History of medicine of the 20th century. Greek pioneers: Zeta Publishers, Athens; 2000.

3. Vilos GA. The history of the Papanicolaou smear and the odyssey of George and Andromache Papanicolaou. Obstet Gynecol. 1998;91:479-83.

4. Papanicolaou GN. New Cancer Diagnosis. In: Proceedings of 3rd Race Betterment Conference, Battle Creek, Michigan, USA 1928, p 528-34.

5. Papanicolaou GN, Traut HF. The diagnostic value of vaginal smears in carcinoma of the uterus. Am J Obstetr Gynecol. 1941;42:193.

6. Papanicolaou GN, Traut HF. The diagnostic value of vaginal smears in carcinoma of the uterus 1941. Arch Pathol Lab Med. 1997;121:211-24. 